\section{Karakteristik Hidrologi Untuk Perencanaan Kolam Konservasi di Lahan Gambut Kecamatan Liang} Anggang

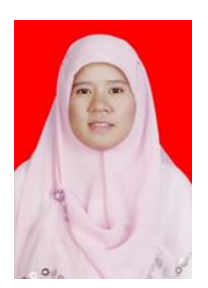

\author{
Ulfa Fitriati
}

Lahir di Barabai 22 September 1981, Alumni Sarjana Universitas Lambung Mangkurat dan Magister Universitas Gajdah Mada. saat ini bekerja di sebagai dosen di Universitas Lambung Mangkurat.ppi@ulm.ac.id

\section{Pendahuluan}

Kebakaran hutan dan lahan di Indonesia tahun 2015 yang lalu merupakan salah satu yang terparah sepanjang sejarah. Lebih dari 2,6 juta hektar hutan, lahan gambut dan lahan lainnya terbakar pada tahun 2015 (BBC, 2016). Untuk wilayah Kalimantan Selatan berdasarkan data pada tahun 2015, jumlah spot hingga 9 November sebanyak 3.264 titik api dengan luas areal yang terbakar yaitu $211.995 \mathrm{Ha}$ atau 5,7 persen dari luas wilayah Kalimantan Selatan. Sedangkan untuk kebakaran lahan gambut di Kota Banjarbaru dan Kabupaten Banjar hingga bulan September 2015 sebanyak 1.536 titik api. (antarakalsel, 2016)

Saat musim kemarau pada tahun 2015 di daerah Kota Banjarbaru dan Kabupaten Banjar terjadi kebakaran di lahan gambut dengan luas sekitar kurang lebih $1500 \mathrm{Ha}$, dimana saat musim kemarau tersebut kondisi lahan gambut terjadi overdrain berlebih yang menyebabkan lahan gambut kering dan memiliki kandungan karbon yang tinggi dan memicu terjadinya kebakaran lahan. Faktor utama kebakaran lahan ini adalah penurunan muka air tanah pada lahan gambut.

Solusi untuk mengatasi kabut asap yang disebabkan oleh kebakaran lahan dengan membuat kanal bloking untuk menahan air seperti membuat penampungan embung untuk menampung air terutama ketika musim hujan agar lahan gambut tetap basah. Restorasi ekosistem gambut dapat dilakukan melalui penataan kembali fungsi hidrologi dimana kubah gambut sebagai penyimpan air jangka panjang (long storage of water), sehingga gambut tetap basah dan sulit terbakar. (Kementrian Lingkungan Hidup dan Kehutanan, 2015)

Penelitian ini bertujuan untuk menganalisa neraca air untuk kolam konservasi di lahan gambut, menganalisa keadaan sifat fisik tanah untuk dibuatnya kolam konservasi di lahan gambut,
Penelitian ini bertujuan untuk menganalisa neraca air untuk kolam konservasi di lahan gambut, menganalisa keadaan sifat fisik tanah untuk dibuatnya kolam konservasi di lahan gambut, mengetahui kondisi muka air tanah di lapangan dan menganalisa kualitas air di sekitar lokasi

www.buletinppi.ulm.ac.id

mengetahui kondisi muka air tanah di lapangan dan menganalisa kualitas air di sekitar lokasi

\section{Hasil Analisa}

\section{Analisis Neraca Air}

Hasil analisis neraca air meliputi perhitungan evapotranspirasi dan analisa curah hujan harian maka didapatkan

Tabel 1. Perhitungan Neraca Air

\begin{tabular}{|c|r|r|r|r|r|}
\hline & $\begin{array}{c}\text { Kumulati } \\
\text { f Input }\end{array}$ & $\begin{array}{c}\text { Kumulati } \\
\text { f Output }\end{array}$ & Storage & $\begin{array}{c}\text { Maksimu } \\
\text { m Input }\end{array}$ & $\begin{array}{c}\text { Minimu } \\
\text { m Output }\end{array}$ \\
\hline $\mathbf{2 0 1 3}$ & 3006,10 & 1333,74 & $\begin{array}{r}1672,3 \\
6\end{array}$ & 87,80 & 1,39 \\
\hline $\mathbf{2 0 1 4}$ & 2351,20 & 1374,29 & 976,91 & 213,90 & 1,45 \\
\hline $\begin{array}{c}\mathbf{2 0 1 3} \\
\mathbf{\&}\end{array}$ & & & 2649,2 & & \\
$\mathbf{2 0 1 4}$ & 5357,30 & 2708,03 & 7 & 213,90 & 211,50 \\
\hline
\end{tabular}

Dari tabel diatas didapatkan nilai tinggi tampungan di akhir tahun pada tahun 2013 sebesar 1672,36 mm dan untuk tahun 2014 sebesar 976,91 mm. Sedangkan untuk kumulatif antara kedua tahun tersebut sebesar $2649,27 \mathrm{~mm}$. 

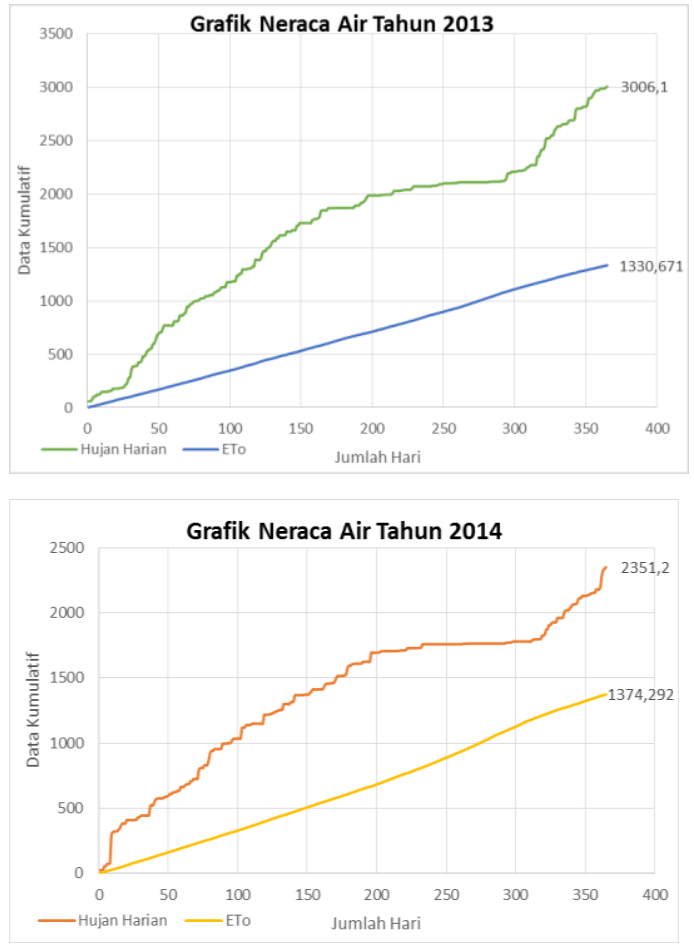

Gambar 1. Grafik Hubungan Curah Hujan vs

Evapotranspirasi

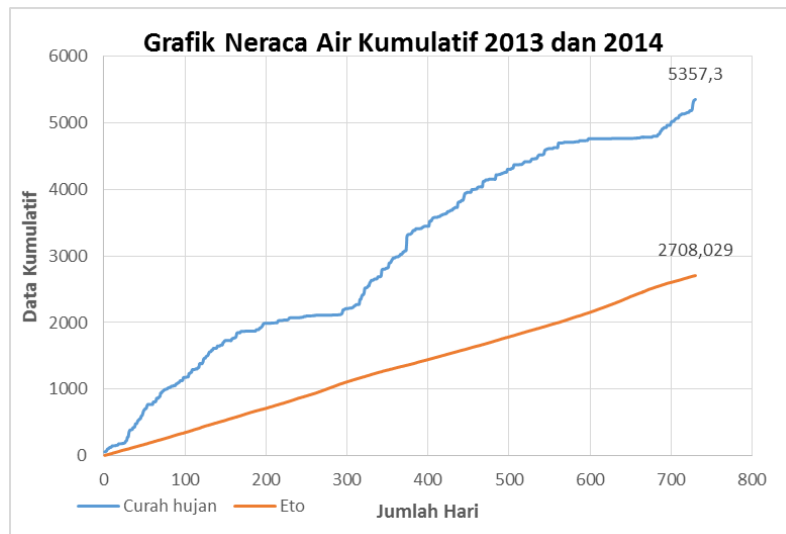

Gambar 2. Grafik Hubungan Curah Hujan vs

\section{Evapotranspirasi Gabungan}

\section{Analisa Kualitas Air}

\section{Pengukuran kualitas air dilokasi}

Hasil analisis kualitas air di lokasi perencanaan kolam konservasi di lahan gambut seluas 900 ha. Titik 1 berada di Jl. Gubernur Syarkawi Km 3,9 Gambut tepatnya berada di Rumah Sakit Jiwa Sambang Lihum dan titik 2 berada di Jalan Sukamara Landasan Ulin. Pengambilan sampel air dilakukan 2 kali, pengambilan sampel air pertama pada tanggal 22 Desember 2016 dan pengambilan sampel air kedua pada tanggal 8 Maret 2017.

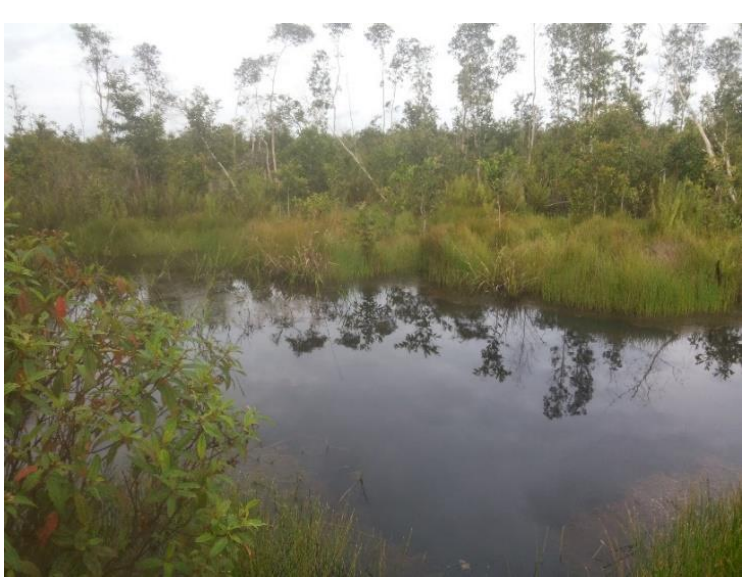

Gambar 3. Kondisi Lokasi Penelitian di Gambut Sambang Lihum

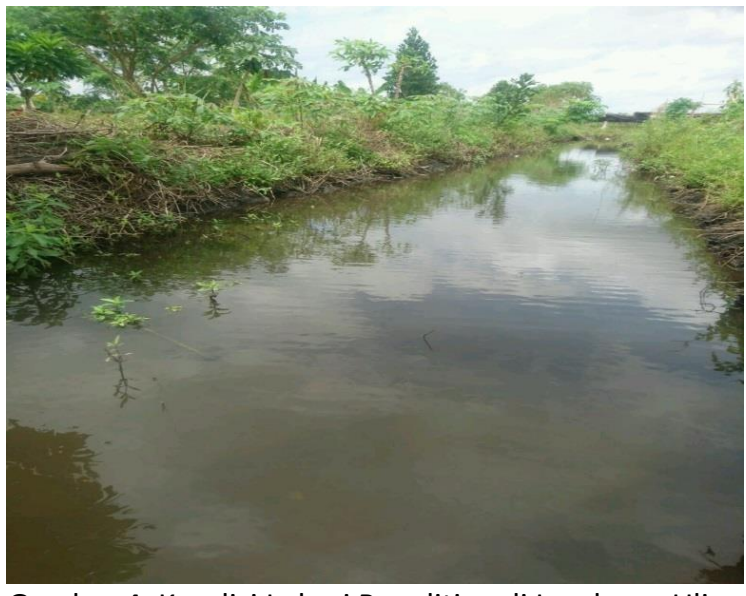

Gambar 4. Kondisi Lokasi Penelitian di Landasan Ulin

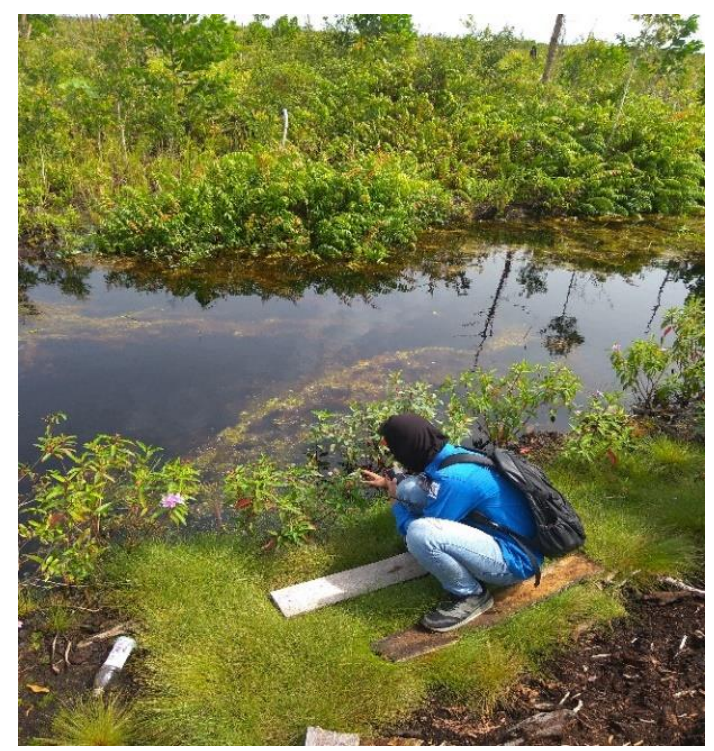

Gambar 5. Pengambilan sampel air untuk pengujian kualitas air 


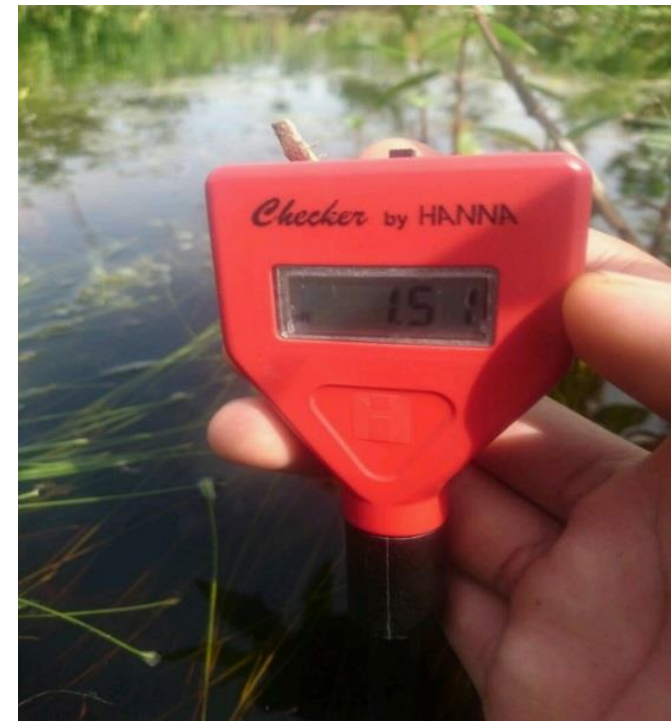

Gambar 6. Pengujian derajat keasaman

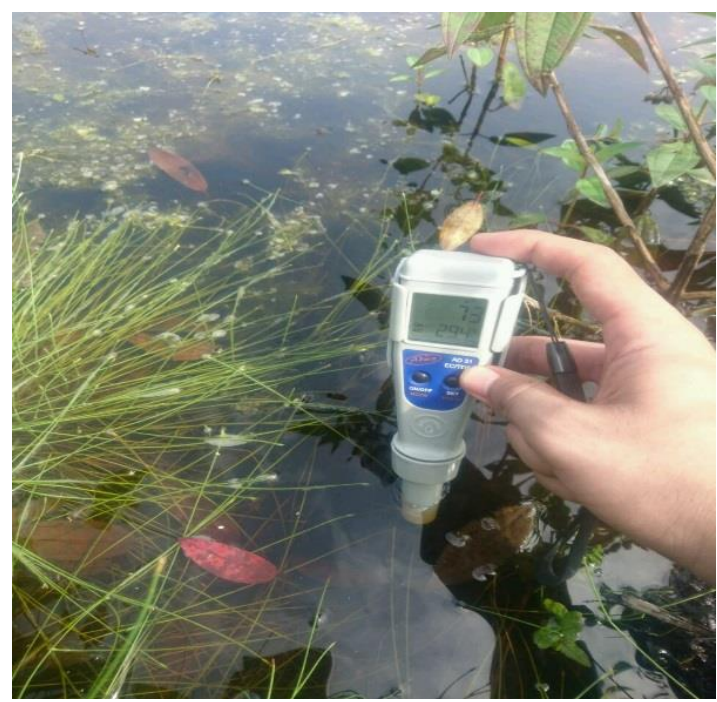

Gambar 7. Pengujian Daya Hantar Listrik

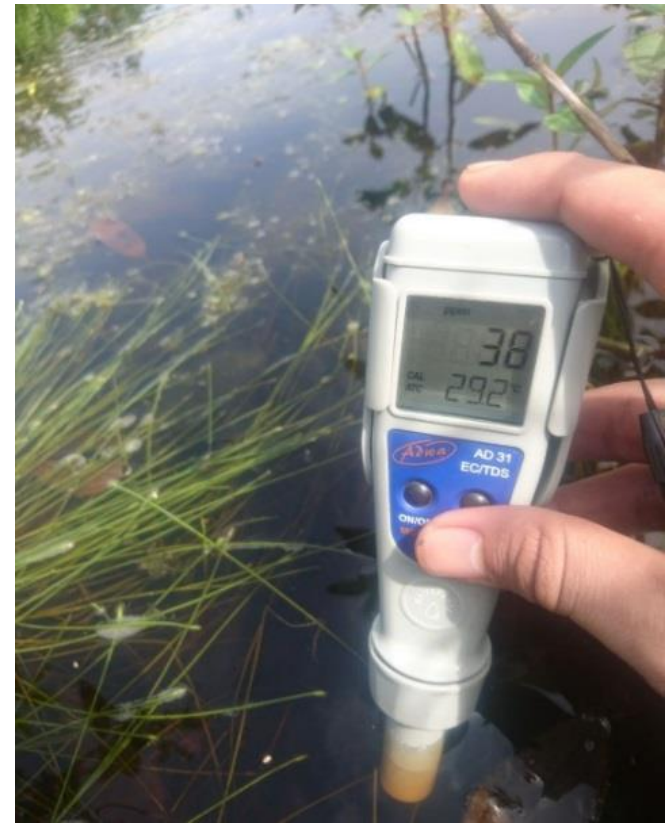

Gambar 8. Pengujian Zat Padat Terlarut
Hasil pengukuran kualitas air dapat dilihat pada tabel berikut:

Tabel 2. Pengukuran kualitas air dilapangan

\begin{tabular}{|c|c|c|c|c|c|c|}
\hline \multirow{2}{*}{ Alat } & \multicolumn{2}{|c|}{ Pengukuran 1} & \multicolumn{2}{|c|}{ Penguk uran 2} & \multirow{2}{*}{\begin{tabular}{|c|} 
Daftar \\
Kua litas \\
Air Gol. D \\
\end{tabular}} & \multirow{2}{*}{ Satuan } \\
\hline & Sampel 1 & Sampel 2 & Sampel 1 & Sampel 2 & & \\
\hline Ec Meter & 75 & 90 & 34 & 95 & & $\mu \mathrm{s} / \mathrm{cm}$ \\
\hline & 0,075 & 0,090 & 0,034 & 0,095 & 2250 & $\mathrm{~ms} / \mathrm{cm}$ \\
\hline TDS Meter & 38 & 61 & 17 & 47 & 2000 & ppm \\
\hline PH Meter & 1,51 & 4,47 & 2,16 & 4,82 & $\geq 4$ & \\
\hline Suhu & 29,4 & 32,4 & 32,3 & 32,1 & \begin{tabular}{|c|} 
Suhu air \\
normal
\end{tabular} & ${ }^{\circ} \mathrm{C}$ \\
\hline
\end{tabular}

Dari hasil pengukuran diatas daya hantar listrik di gambut cenderung rendah, sedangkan daya hantar listrik di Landasan Ulin nilai kepekatannya juga rendah. Pengujian Total Disolved Solids (TDS) atau jumlah padatan terlarut sangat kecil, sedangkan di Landasan Ulin nilai jumlah padatan terlarutnya juga kecil. Meskipun antara kedua lokasi nilai jumlah padatan terlarutnya kecil tetapi di Landasan Ulin lebih tinggi dari pada nilai jumlah padatan terlarut di daerah Gambut. Pada daerah Gambut dan Landasan Ulin memiliki tingkat keasaman yang rendah sehingga dapat diartikan $\mathrm{pH}$ di kedua lokasi tersebut asam.

Pengukuran kualitas air di laboratorium Hasil uji kualitas air di laboratorium ditampilkan pada tabel dibawah ini :

Tabel 3. Hasil pengujian kualitas air di laboratorium

\begin{tabular}{|c|c|c|c|c|c|c|c|c|c|c|c|}
\hline & Suhu $\left({ }^{\circ} \mathrm{C}\right)$ & $\mathrm{pH}$ & $\mathrm{pHmV}$ & ORPmV & $\mathrm{mS} / \mathrm{cm}$ & NTU & $\mathrm{mg} / \mathrm{L}$ D0 & $\%$ D0 & $\mathrm{g} / \mathrm{L}$ TDS & $\mathrm{ppt}$ & ot \\
\hline Sampel 1 & 30,14 & 5,47 & 110 & 307 & 0,024 & 22,7 & 7,6 & 101,4 & 0,015 & 0 & 0 \\
\hline Sampel 2 & 28,58 & 5,8 & 92 & 279 & 0,071 & 22,55 & 8,16 & 106,2 & 0,043 & 0 & 0 \\
\hline
\end{tabular}

Hasil pengujian di laboratorium untuk pengukuran 2. Dapat dilihat bahwa untuk pengujian daya hantar listrik di gambut rendah meskipun nilai pengujian di laboratorium dan di lapangan berbeda serta suhu berbeda. Hal ini disebabkan karena terjadinya perubahan secara kimiawi dan biologis seiring waktu. Perubahan juga terjadi dikarenakan tergoncang saat perjalanan ke laboratorium yang menyebabkan terbentuknya endapan dan ruang udara yang berubah.

Dari hasil analisa diatas dapat dibandingkan antara pengujian dilapangan dimana untuk daerah gambut nilai $\mathrm{pH}$ sangat berubah. Meskipun tetap dikategorikan asam tetapi nilai $\mathrm{pH}$ jauh berubah dari 2,16 menjadi 5,47. Hal ini disebabkan oleh ruang udara pada botol yang mempengaruhi karena ada resiko udara larut ke dalam sampel air.

Dari pengujian diatas dapat disimpulkan dari untuk daerah Gambut dan Landasan Ulin nilai DHL nya cenderung rendah. Nilai zat padat terlarut sangat kecil yaitu antara $17 \mathrm{ppm}$ sampai $61 \mathrm{ppm}$, angka ini sangat rendah dibandingkan dengan daftar 
kriteria kualitas air golongan. Dapat dibandingkan juga untuk nilai $\mathrm{pH}$ pada kedua lokasi nilainya dibawah 7 yang menandakan sifat air tersebut asam.

Hasil analisis kualitas air ini yang mengacu pada daftar kriteria kualitas air golongan D (air yang digunakan untuk keperluan pertanian serta usaha perkotaan, industri, dan pembangkit tenaga air) dengan demikian masih memenuhi syarat untuk kategori kualitas air golongan D yang bisa dimanfaatkan untuk keperluan pertanian serta usaha perkotaan, industri, dan pembangkit listrik tenaga air.

\section{Kesimpulan}

1. Hasil analisis neraca air didapatkan nilai tinggi tampungan di akhir tahun pada tahun 2013 sebesar 1672,363 $\mathrm{mm}$ dan pada tahun 2014 total kumulatif diakhir tahun sebesar 976,908 $\mathrm{mm}$. Sedangkan untuk total tampungan diakhir tahun kumulatif sebesar 2649,271 mm.

2. Hasil analisa kualitas air pada tanah gambut Kecamatan Liang Anggang memenuhi syarat untuk kategori kualitas air golongan D yang bisa dimanfaatkan untuk keperluan pertanian serta usaha perkotaan, industri, dan pembangkit listrik tenaga air.

\section{Ucapan Terimakasih}

Ucapan Terimakasih kami sampaikan kepada pihakpihak yang berperan dalam kelancaran dan keberhasilan pelaksanaan penelitian ini yaitu :

1. ALLAH Subhanahuwata'ala, atas segala kemudahan dan keselamatan yang telah diberikan.

2. Melinda Ayunita Santoso, ST sebagai bagian dari skripsi yang bersangkutan yang saya bombing.

3. M. Afief Ma'ruf, MT sebagai dosen co. pembimbing

4. Instruktur laboratorium hidrolika yang membantu dalam pengambilan sampel dan uji kualitas air.

\section{Referensi}

1. Agus, F., \& Subiksa, I. M. (2008). Lahan Gambut: Potensi untuk Pertanian dan Aspek Lingkungan. Bogor, Indonesia: Balai Penelitian Tanah dan World Agroforestry Centre (ICRAF).

2. Allen et all. (1998). Crop Evapotranspiration. FAO Irrigation and Drainage Paper.

3. Anonim (1986). Standar Perencanaan Irigasi (KP01) Departemen Pekerjaan Umum. Bandung: Galang Persada.

4. Antarakalsel. (2016). Perlu Ahli Tangani Kebakaran Gambut. Banjarmasin.
5. Asdak, C. (1995). Hidrologi dan Pengelolaan Daerah Aliran Sungai. Yogyakarta: Gajah Muda University Press.

6. BBC, I. (2016). Dapatkah kebakaran di Indonesia diakhiri? Jakarta: Sarah Porter.

7. Kementrian Lingkungan Hidup dan Kehutanan. (2015). Pedoman Pemulihan Ekosistem Gambut. Jakarta.

8. Kodoatie J., R., \& Sjarief, \&. R. (2010). Tata Ruang Air. Yogyakarta: Penerbit Andi.

9. MacFarlane, I. (1965). Muskeg Engineering Handbook. Toronto, Canada: Natoinal Research Council of Canada, University of Toronto.

10. Noor, M. (2001). Pertanian Lahan Gambut . Yogyakarta: Kanisius.

11. Nugroho, W. C., \& dkk. (2004). Panduan Pengendalian Kebakaran Hutan dan Lahan Gambut. Bogor: Wetlands International Indonesia Programme.

12. Peraturan Pemerintah Republik Indonesia Nomor 73 Tahun 2013. (2013). Rawa. Lembaran Negara Republik Indonesia.

13. Soemarto B.I.E Dipl H, I. (1987). Hidrologi Teknik. Surabaya: Usaha Nasional.

14. WWFINDONESIA. (2015). ForestFire. Diambil kembali dari Mungkinkah Penurunan Titik Panas Tercapai?: http://www.wwf.or.id/tentang_wwf/upaya_kami/i klim_dan_energi/solusikami/adaptasi/forest_fire.c $\mathrm{fm}$ 